\title{
Modelling of the Annual Mean Urban Heat Island Pattern for Planning of Representative Urban Climate Station Network
}

\author{
János Unger, ${ }^{1}$ Stevan Savić, ${ }^{2}$ and Tamás Gál ${ }^{1}$ \\ ${ }^{1}$ Department of Climatology and Landscape Ecology, University of Szeged, P.O. Box 653, 6701 Szeged, Hungary \\ ${ }^{2}$ Climatology and Hydrology Research Centre, Faculty of Science, University of Novi Sad, Trg Dositeja Obradovića 3, \\ 21000 Novi Sad, Serbia
}

Correspondence should be addressed to János Unger, unger@geo.u-szeged.hu

Received 22 December 2010; Revised 26 April 2011; Accepted 10 August 2011

Academic Editor: C. S. B. Grimmond

Copyright (C) 2011 János Unger et al. This is an open access article distributed under the Creative Commons Attribution License, which permits unrestricted use, distribution, and reproduction in any medium, provided the original work is properly cited.

\begin{abstract}
The spatial distribution of the annual mean urban heat island (UHI) intensity pattern was analysed for the medium-sized city Novi Sad, Serbia, located on the low and flat Great Hungarian Plain. The UHI pattern was determined by an empirical modelling method developed by (Balázs et al. 2009). This method was based on datasets from urban areas of Szeged and Debrecen (Hungary). The urban study area in Novi Sad $\left(60 \mathrm{~km}^{2}\right)$ was established as a grid network of 240 cells $(0.5 \mathrm{~km} \times 0.5 \mathrm{~km})$. A Landsat satellite image (from June 2006) was used in order to evaluate normalized difference vegetation index and built-up ratio by cells. The pattern of the obtained UHI intensity values show concentric-like shapes when drawn as isotherms, mostly increase from the suburbs towards the inner urban areas. Results of this thermal pattern and determination of one of the local climate classification systems were used for recommending 10 locations for representative stations of an urban climate network in Novi Sad.
\end{abstract}

\section{Introduction}

In the second part of the 20th century, urbanization accelerated and reached enormous magnitude. The growth rate of the Earth's urban population is greater than that of the total population; therefore, more and more people live in urbanized regions. Nowadays, about half of the human population is affected by the burdens of urban environments: environmental pollution, noise, stress of the accelerated life-style, and last but not least the modified parameters of the urban atmosphere compared to the natural environment. This makes studies dealing with the urban impact on climate particularly important.

Not only the large cities but also the smaller ones modify materials, structure, and energy balance of the surface and almost all properties of the urban atmospheric environment compared to the natural surroundings. Thus, owing to the artificial factors, a local climate (urban climate) develops which means a modification to the preurban situation. This climate is a result of the construction of buildings as well as by the emission of heat, moisture, and pollution related to human activities.
According to Oke [1], two layers can be distinguished in the urban atmosphere. The first one is the urban canopy layer (UCL) containing air between the urban roughness elements (mainly buildings). It is a microscale concept, and its climate is dominated geographical factors and modified by the nature of the immediate surroundings. The upper boundary of the UCL is at about roof level. The second layer is the urban boundary layer (UBL) which is situated directly above the first layer. This is a local or mesoscale concept whose characteristics are governed by the nature of the whole urban area.

In the course of urban climate development, the nearsurface air or (UCL) temperature shows the most obvious modification compared to the rural area [2]. This urban warming is commonly referred to as the urban heat island (UHI), and it is a good example of inadvertent climatic change. We note that all temperatures referred to this study are in the UCL at 1.5-2 metres above ground level.

It is anticipated that continuous, quality-assured observations provide new research opportunities focused on the spatial and temporal variability in UHI patterns. In order to acquire long-term data as a basis for studies, measurements 
in a network established in the city are needed. Selecting the exact sites of the individual stations to ensure the representativeness of the thermal conditions across a wider area in the complex urban environment is a difficult problem [3]. Theoretically, this representativeness can only be assessed in the context of its micro-, and local-scale properties of surface geometry (sky view factor, height-to-width ratios, and aerodynamical roughness length), cover (percentage of built material, albedo, and thermal admittance), and artificial heat (space heating/cooling and traffic density) [4]. If the aim is to monitor local climate attributable to an urban area, it makes sense to avoid locations with extreme microclimatic influences or nonurban local climatic phenomena that may complicate the urban record.

Methodologically, determination of the temperature increasing effect of an urban area means the calculation of difference between the temperature values measured at representative "rural" and "urban" sites. In order to classify these sites, several classification systems exists [3,5-7], and these classify the terrain into different areas called for example, Urban Climate Zones [3] or Local Climate Zones (LCZ) [5]. LCZs are defined by Stewart [6] as regions of relatively uniform surface-air temperature distribution across horizontal scales of $10^{2}$ to $10^{4}$ metres. The LCZ system is currently under development by Stewart and Oke, and thus, the version used in this paper is a prototype, as given in [7], and consists of 16 zones in urban, rural, and transitional areas.

Given the above-mentioned requirements for siting an urban climate network, two initial steps can be regarded as highly useful:

(1) (a) conducting some preliminary mobile spatial surveys traversed through areas of interest to see where are the areas of thermal anomaly of interest or (b) modelling the general thermal patterns by applying the obtained results from other cities with similar environmental conditions and built-up structures,

(2) mapping of some type of climate zone classifications (e.g., LCZ system in [7]) within the urban area of the city. The importance of this kind of classification lays not in the absolute accuracy of a given type to describe the site but in its ability to classify areas of a settlement with similar capacities of modifying the local climate [2]. Such classification is crucial when setting up an urban station to ensure that spatial homogeneity criteria are met for a station in the UCL.

The climate zone classification systems were not originally designed for mapping, it was designed to classify and standardize urban heat island observation sites, whether urban or rural, fixed or mobile. If the aim is to establish a new urban station network, the mapping seems to be a good application of the system for delineating the approximate sites of the stations representing a wider urban area.

The main objectives of this study are:

(a) to determine the built-up density distribution and the mean pattern of nocturnal urban canopy layer UHI intensity in the city of Novi Sad, Serbia using a model developed by [8], (b) to map the climate zones using the LCZ system in [7] in the studied urban area,

(c) to determine the possible sites of the stations of a planned urban climate network in Novi Sad based on the obtained UHI pattern in (a) and the map of the climate zone classification in (b). The three existing stations (one in urban and two in rural zones) would be expanded with the recommended urban station network providing high-time frequency data of main climate parameters (air temperature and humidity, global radiation, and precipitation). The main purposes of this combined network are (i) to monitor the seasonal and diurnal patterns of the urban heat island in the UCL of Novi Sad and (ii) to determine areas inside the city being less stressful for the citizens during the more and more frequent heat waves using thermal comfort indices.

\section{Study Area}

Novi Sad is located in the northern part of Serbia (Vojvodina Province), that is, on the southern part of the Great Hungarian Plain $\left(45^{\circ} 15^{\prime} \mathrm{N}, 19^{\circ} 50^{\prime} \mathrm{E}\right)$ (Figure 1). The investigated area is plain (mostly from 80 to $86 \mathrm{~m}$ a.s.l.) on Holocene sediments with a gentle relief, so generally, the climate is free from orographic effects. The river Danube passes on the southern and eastern edge of the urban area, and its width varies from 260 to 680 meters. The relatively narrow DTD channel (Danube-Tisza-Danube) passes through the northern part of the city and its climatic influence is probably negligible. South of the Novi Sad urban area, the northern slopes of Fruška Gora Mountains are located (the highest peak is $538 \mathrm{~m}$ a.s.l.) which descend steeply towards the Danube.

According to Köppen-Geiger climate classification, the region around Novi Sad is categorised as Cf climate (temperate warm climate with a rather uniform annual distribution of precipitation) $[10,11]$. In Novi Sad, the annual mean air temperature is $11.1^{\circ} \mathrm{C}$ with an annual range of $22.1^{\circ} \mathrm{C}$. The mean annual precipitation amount is $615 \mathrm{~mm}$ (based on data from 1949 to 2008). Szeged and Debrecen in Hungary, whose UHI and surface cover data were used for the development of the applied statistical method [8], are also in climate region Cf [11].

Novi Sad is the second largest city in Serbia (and in the mentioned geographical region) and has a population of 285,756 inhabitants (data from 2009) in a built-up area of approximately $60 \mathrm{~km}^{2}$.

The recent city structure and the main buildings in the inner parts of these cities (Novi Sad, Szeged, and Debrecen) were developed at around the turn of the 20th century, and until the end of the World War 1, these cities belonged to the same country (Hungary). After this time, the development of the settlements in this region was almost parallel. After the Second World War, in both countries there were social regimes with similar urbanization policy and architecture (from 1945 until nineties). Therefore, these cities in Hungary and Serbia have very similar urban structure. 


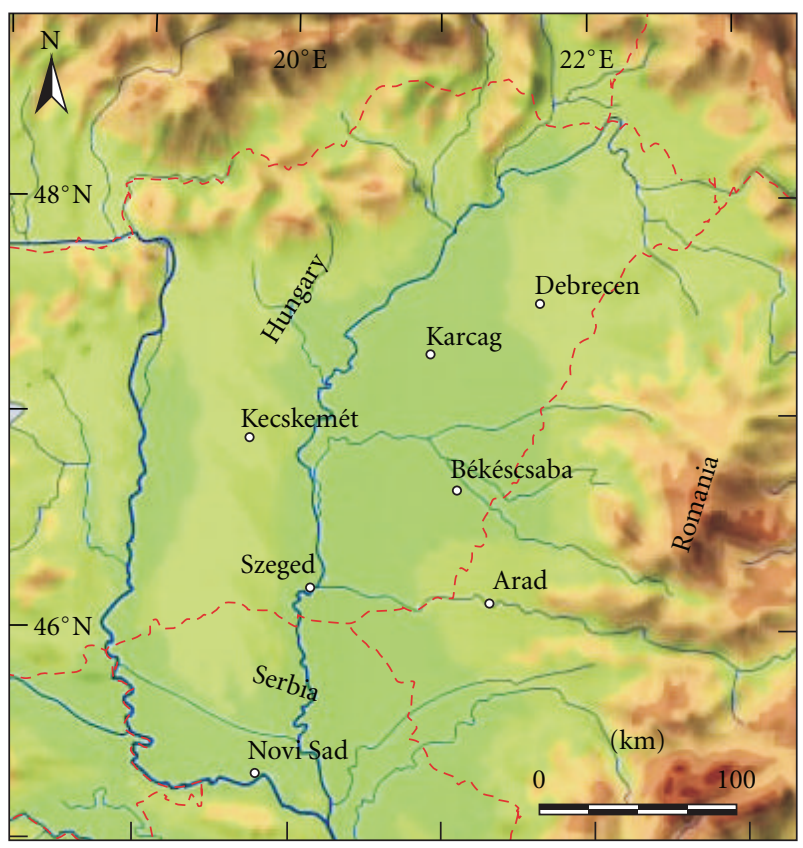

Figure 1: Locations of Novi Sad and the investigated cities in [8] with the relief map [9] of the Great Hungarian Plain and country borders (dashed lines).

Novi Sad has a densely built central area with mediumwide streets and avenue-boulevard roads network connecting different areas of the city. Around the city's central part, there are areas occupied by tall apartment buildings (mostly from 4 to 8 stories and with few examples with more than 10 stories) set in wide green space and detached houses (in most cases with 1 story). In the northern part, Novi Sad also contains zones used for industry and warehousing (flat and horizontal buildings, not higher than $10 \mathrm{~m}$, i.e., 3 stories), and open space along the banks of the Danube, in parks, and around the city's outskirts.

In and around Novi Sad, four meteorological stations have been established in the last 60 years. The main meteorological station Rimski Šančevi (network of Republic Hydrometeorological Sevice) is situated in rural area $\left(45^{\circ} 19^{\prime} \mathrm{N}\right.$, $19^{\circ} 49^{\prime} \mathrm{E}, 84 \mathrm{~m}$ a.s.l.), $1.9 \mathrm{~km}$ from the northern outskirts of the city and in $7.5 \mathrm{~km}$ distance from downtown (E1 in Figure 7(a)). The meteorological station was established in 1949, and up to now, it provides an undisturbed time series longer than 60 years. The Petrovaradin meteorological station was established in the middle of 20th century, and observations were taken in the period between 1956 and 1992. The station was situated in the southeastern part of the urban area at the Petrovaradin fortress $\left(45^{\circ} 15^{\prime} \mathrm{N}, 19^{\circ} 52^{\prime} \mathrm{E}, 132 \mathrm{~m}\right.$ a.s.l. $)$ between compact lowrise apartment buildings and green space outskirts. Two automatic weather stations (AWS) were set up in 2009. The first AWS is situated at the Petrovaradin fortress (E2 in Figure 7(a)) and replaces of the closed Petrovaradin meteorological station, and the second one is situated in the rural zone (village Kać) approximately $9 \mathrm{~km}$ from Novi Sad downtown (E3 in Figure 7(a)). All mentioned stations measure or measured parameters like air temperature, precipitation, air humidity, winds, air pressure and various indices.

\section{Previous UHI Investigations in Novi Sad}

So far, a small number of papers have been published considering UHI investigations in Novi Sad. The first publication is theoretically based that is, it presents all parameters, methods and measurements which have to be used in order to work on UHI research of Novi Sad [12]. The next studies analyzed temperature values based on 30-40 year long time series (until 1990) [13, 14]. These studies used one rural (Rimski Šančevi) and one urban (Petrovaradin fortress) stations (see Figure 7). As the results showed, there are increasing trends of mean, maximum, and minimum temperatures at Petrovaradin, and in most cases, these trends are higher than trends at Rimski Šančevi. Based on meteorological parameters and the structure of urban area, Popov and Savić [15] showed the necessity of defining locations of an urban climate network in order to advance further UHI research in Novi Sad.

\section{Method for Modelling the Mean UHI Pattern in Novi Sad}

The applied method for the determination of the suspected spatial structure of the mean annual UHI intensity in Novi Sad is based on the study of Balázs et al. [8]. The main advantage of this regression method was to predict the spatial distribution of the annual mean UHI using just a few input parameters which can be determined in a simple way (remote sensing) without having detailed local information about the city. In this section, a short description is given on the UHI modelling in general and also on the used method (for more details, see Balázs et al. [8]).

4.1. Modelling the UHI Patterns. According to Oke [16] and Svensson et al. [17], three types of models can be applied for climate related research in urban environments: numerical, physical, and empirically based models. The advantage of the empirical models is that they are based on observed statistical properties, but their disadvantage is that they are often restricted to a specific location. Among the empirical models, statistical approaches are the most common methods to reveal relationships between the canopy layer UHI intensity and the meteorological as well as other physical parameters (including variables describing surface properties) which influence its formation. Thus, these models may provide useful quantitative information on the roles of the above-mentioned parameters in the development and spatial distribution of the UHI (e.g., [18-21]).

The spatial distribution of $\Delta T$ (UHI intensity) exhibits seasonal and diurnal variations as a result of meteorological and urban characteristics and location [2]. Simplifying the factors of a location (topography, water bodies) to a flat area and considering the annual mean UHI, its form and size are mainly a result of the urban factors $[22,23]$. There are several studies which simulate $\Delta T$ using partly or entirely urban surface features as independent variables (e.g., [24-28]). 
It has to be mentioned that the weakness of most of these studies is the lack of validation.

As detailed collection of urban data is complicated and requires significant technical investment, satellite images of settlements situated on a plain (no orographical influence) can serve as a tool to estimate the mean UHI intensity, because some parameters (e.g., covered or built-up surfaces) of the artificial urban environment can be easily determined through the evaluation of these images.

Experiments to model the spatial distribution of canopy layer $\Delta T$ for relatively large (several dozens of $\mathrm{km}^{2}$ or more) urban areas are rather scarce. Some of them are listed in chronological order as follows: a numerical model for a $140 \mathrm{~km}^{2}$ area of Christchurch, New Zealand [29], empirical models for a $\sim 120 \mathrm{~km}^{2}$ area of Łódź, Poland [30], for a $700 \mathrm{~km}^{2}$ area of Göteborg and its wide surroundings [17], for a $\sim 30 \mathrm{~km}^{2}$ area of Szeged, Hungary [31], and for a $\sim 30 \mathrm{~km}^{2}$ area of Debrecen, Hungary [32], and a numerical model for a $\sim 400 \mathrm{~km}^{2}$ area of Rome, Italy [33].

The empirical modelling study of Balázs et al. [8] dealt with UHI patterns of cities located in a rather homogeneous region therefore, it is more region than site specific. As we used their method, we give a short description of it. Datasets from Szeged (population 165000 ) and Debrecen (population 204000 ) situated on the Great Hungarian Plain in Hungary (Figure 1) were used to construct their empirical model. The measurements and modelling focused on the urbanized areas, about $30 \mathrm{~km}^{2}$ for both cities. According to the original project plan, the annual mean UHI patterns of fifteen cities with different sizes and population, situated on the Great Hungarian Plain, were to be modelled using the obtained empirical model regardless of the existing country borders. As examples, Balázs et al. [8] presented modelled UHI patterns of only four of these cities.

4.2. Dependent Variable: UHI Intensity. For the information on the UHI intensity and its pattern (as dependent variable), temperature data were collected by mobile measurements in the urban areas of Szeged and Debrecen, which were divided into $0.5 \mathrm{~km} \times 0.5 \mathrm{~km}$ grid cells. The study areas consisted of 107 cells $\left(25.75 \mathrm{~km}^{2}\right)$ in Szeged and 105 cells $\left(26 \mathrm{~km}^{2}\right)$ in Debrecen and covered the inner and suburban parts of the cities. One rural cell in both cities was used as a reference area for the comparison of temperature data. These cells are located outside of the cities, and their areas are agricultural fields with cereals and corn, that is, both cells belong to the LCZ "Low plant cover" [7], so they can be characterized as rural.

The required data were collected by cars on assigned routes, in a one-year period between April, 2002 and March, 2003. The survey routes passed through all cells but not always through the centre of them, since they were constricted by the road network. As the temperature does not vary abruptly within short distances, the obtained values can be regarded as repsentative ones for the cells. This type of mobile measurement is widespread in observing urban climate parameters (e.g., $[34,35])$. The measurements took place at a frequency of about 10 days simultaneously, altogether 35 times in both cities. They were carried out under all kinds of

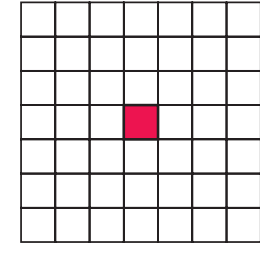

$B_{0}$

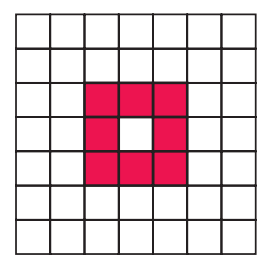

$B_{1}$

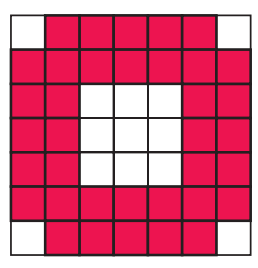

$B_{2}$
Figure 2: Cells which take part in the calculation of $B_{0}, B_{1}$, and $B_{2}$ surface parameters.

weather conditions except rain. Based on experiences from previous studies, data collection took place at around the expected time of the daily maximum development of the UHI, which is 4 hours after sunset (e.g., $[36,37])$. The UHI intensity $(\Delta T)$ by cells is defined as follows [19]:

$$
\Delta T=T_{\text {cell }}-T_{\text {cell }(\mathrm{R})},
$$

where $T_{\text {cell }}=$ temperature of an urban cell and $T_{\text {cell }(\mathrm{R})}=$ temperature of the rural cell. Annual mean $\Delta T$ s were determined by averaging the $\Delta T$ values of the 35 measurements by cells.

4.3. Independent Variables. As independent variables for estimating the UHI field, 2D urban surface cover data and the distance from the city boundary were determined for each element of the $0.5 \mathrm{~km} \times 0.5 \mathrm{~km}$ mesh in the study areas in Szeged and Debrecen.

The artificially covered surface ratio (streets, pavements, parking lots, roofs, etc.), or built-up ratio $\left(B_{0}\right)$, horizontally characterizes the surface of a settlement. This parameter was determined for each cell using GIS (geographical information system) methods combined with the remote sensing analysis of Landsat satellite images [19]. The satellite images were taken in 2000, so they provide accurate data on the built-up conditions in the time of temperature measurements (2002-2003). Normalised difference vegetation index (NDVI) was calculated from the pixel values $[38,39]$, then the ratio of water, built-up, and vegetation surfaces in each cell were determined with this index by cells.

It is also important to consider the surface conditions around the cells, because the wider surroundings can influence the temperature of a given cell. In order to take the effect of the surroundings into account, a set of derived variables (average built-up ratio of concentric areal extensions around the cells, $B_{1}, B_{2}$ ) were constructed (Figure 2). The distinction of urban and rural cells based on an arbitrary but low value of $B_{0}$. If $B_{0}<5 \%$, then the cell is considered rural, otherwise urban. This threshold ensures that cells defined as rural correspond with landscapes of cropped fields and few roads or buildings. The obtained zones of surface variables cover the entire study areas and their $1.5 \mathrm{~km}$ wide extensions in the investigated settlements. These extensions are needed in the calculations of $B_{1}$ and $B_{2}$ parameters for cells near the edges of study areas.

The distance (from the city centre or from the boundary) can be regarded as a parameter that characterizes the location of a place inside the city. That is, considering the areas with 

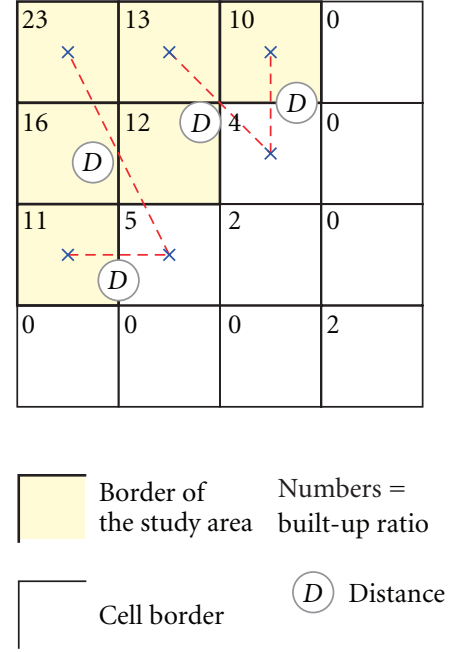

Figure 3: Examples for the determination of the distance $(D)$ (built-up ratios are in \%).

the same building structure and design in the suburbs and in the centre, a reduced $\Delta T$ can be experienced in the suburbs compared to that in the centre. Now, the distance from the city boundary ( $D$ in $\mathrm{m}$ ) is considered. This $D$ is defined as the distance between a given cell inside the study area and the nearest cell with a built-up ratio of less than $5 \%$ outside the study area (Figure 3).

In order to take into account the integrated affects of distance $(D)$ and the above-mentioned surface parameters $\left(B_{0}\right.$, $B_{1}$, and $\left.B_{2}\right)$ in the formation of UHI, some new combined urban parameters were constructed (marked by apostrophes: $B_{0}{ }^{\prime}, B_{1}{ }^{\prime}$, and $B_{2}{ }^{\prime}$ ). Based on the work of Fortuniak [20], distance is considered as $\ln D$. So, the combined parameters are generated by multiplying (or weighing) the surface parameters by the logarithmic distance by cells:

(i) parameter $B_{0}{ }^{\prime}=B_{0} \cdot \ln D$,

(ii) parameter $B_{1}{ }^{\prime}=B_{1} \cdot \ln D$,

(iii) parameter $B_{2}{ }^{\prime}=B_{2} \cdot \ln D$.

4.4. Construction of the Multiple-Parameter Models. The relationship between the obtained combined urban surface parameters and the annual mean UHI intensity were determined to construct a general multiple-parameter model based on data from Szeged and Debrecen which can be used for the estimation of mean $\Delta T$ patterns in other settlements situated on a plain. The elements of the model are the following:

(i) $\Delta T$, as variable parameter $\left({ }^{\circ} \mathrm{C}\right)$,

(ii) $B_{0}{ }^{\prime}, B_{1}{ }^{\prime}, B_{2}{ }^{\prime}$, as invariable parameters.

A stepwise multiple regression analysis was done with SPSS 11 software in order to compute the model equation [40]. The equation takes the following form:

$$
\Delta T=0.001032 \cdot B_{0}{ }^{\prime}+0.002455 \cdot B_{1}{ }^{\prime}+0.002629 \cdot B_{2}{ }^{\prime} .
$$

TABLE 1: Validity intervals of the basic parameters for the obtained model based on the datasets of Balázs et al. [8].

\begin{tabular}{lcc}
\hline Parameter & Min & Max \\
\hline$B_{0}(\%)$ & 0 & 85.5 \\
$B_{1}(\%)$ & 0.1 & 63.1 \\
$B_{2}(\%)$ & 8.1 & 49.7 \\
$D(\mathrm{~m})$ & $0<$ & 3162 \\
\hline
\end{tabular}

Based on the ranges of the applied datasets from Szeged and Debrecen, the obtained model equation can be regarded as strictly valid in the parameter intervals presented in (Table 1). The equation has no constant; therefore, if the invariable parameters are equal to zero, the equation gives an UHI intensity of zero. It is in line with the experience that the unbuilt or barely built areas do not generate any temperature excess.

In order to properly test the obtained model equation, temperature datasets from three settlements having similar environmental conditions but being independent from those of Szeged and Debrecen were used. As a result, there was good correspondence between the measured values and the estimated ones by the model [8].

This general model was extended to other, different-sized settlements (Karcag, Kecskemét, Békéscsaba, and Arad), where the environment, like topography and climate, is similar to that of Szeged and Debrecen without taking country borders into account. As mentioned earlier, only certain Landsat satellite images of the settlements are necessary, from which the built-up ratio and its areal extensions (weighing with the log-distance from the city border) can be determined as independent variables for this purpose. The standard Kriging method and linear variogram model of Surfer 8 software were used to interpolate the temperature values by cells and for the spatial tracing of the isotherms [41, 42]). For the obtained UHI pattern, Balázs et al. [8], see Figures 8-11.

The obtained model equation can be considered applicable and appropriate for other cities of different size if the invariable parameter values of the study areas are within the intervals given in Table 1. Now, we apply the model to the city of Novi Sad (Serbia) situated at the edge of the Great Hungarian Plain not far $(115 \mathrm{~km})$ from Szeged (Figure 1).

\section{Results and Discussion}

5.1. Patterns of Built-Up Ratio and Modelled Mean UHI Intensity in the Study Area. According to the methods described in Section 4 , first, a grid network $(500 \times 500 \mathrm{~m})$ was established which contains the study area (240 cells) and its $1.5 \mathrm{~km}$ wide extension in and around Novi Sad. It covers the main urban areas of the city without the satellite settlements around it (Figure 4). The UTM coordinates of the NW and SE corners of the rectangle containing the grid network are 34T 400500 5019000 and 34T 4150005000500 , respectively.

A Landsat satellite image taken at June 26, 2006 [43] was used for the evaluation of NDVI and then of built-up ratio $\left(B_{0}\right)$ by cells. The built-up ratio inside the study area ranges from values near $0 \%$ to values over $90 \%$ because of the River 

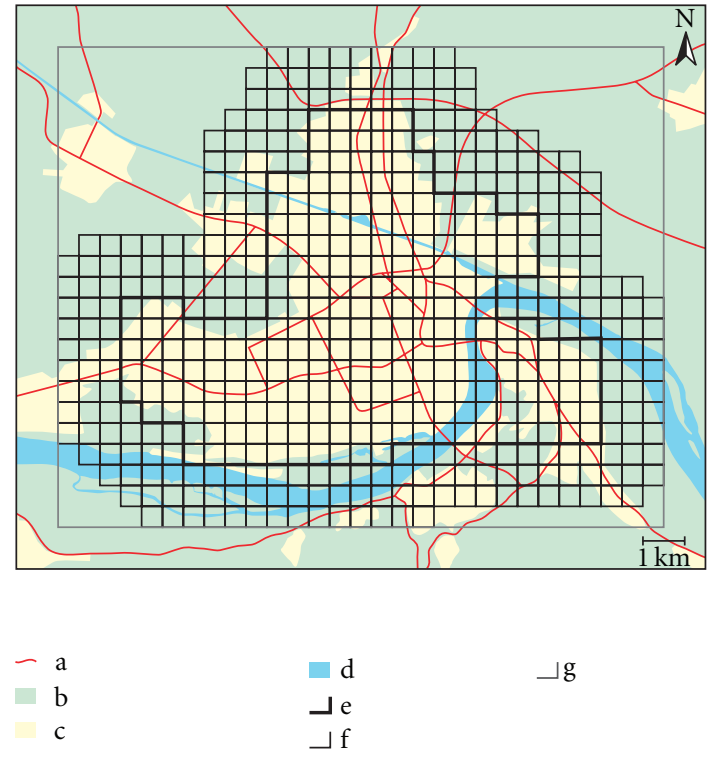

FIGURE 4: Grid network of the study area with its $1.5 \mathrm{~km}$ wide extension in Novi Sad: (a) main roads, (b) rural areas, (c) urban areas, (d) water bodies, (e) border of the study area, (f) cell border in the study area and in its extension, and ( $\mathrm{g}$ ) border of the rectangle containing the grid network.

Danube and the densely built-up city centre (Figure 5). Large density can be found in the central part of the study area (about 30 cells) with the highest $B$ values in its eastern areas near the Danube (in 10 neighbouring cells). More local builtup maxima are located in the western, northern, north-eastern and eastern, parts of the study area.

Based on the $B_{0}$ values, the other two built-up parameters $B_{1}$ and $B_{2}$, as well as the distance parameter $D$, were determined for each of the 240 cells of the study area. In order to model the annual mean UHI intensity values by cells, the combinations of these parameters $\left(B_{0}{ }^{\prime}, B_{1}{ }^{\prime}, B_{2}{ }^{\prime}\right)$ were calculated and then substituted into (2). As mentioned in Section 4, the development of the empirical model was based on the dataset of Szeged and Debrecen, so the largest $B_{0}$ values in Novi Sad slightly exceed the base data (see Table 1). This means a slight extrapolation of the model for certain cells (less than $10 \%$ of the cells) therefore, the obtained $\Delta T$ values in these cases should be treated cautiously. However, we are sure that the structure of the obtained $\Delta T$ field certainly reflects the main characteristic of the pattern of the UHI in Novi Sad (Figure 5).

As the predictors $\left(B_{0}{ }^{\prime}, B_{1}{ }^{\prime}, B_{2}{ }^{\prime}\right)$ of the model based primarily on the built-up ratio of the cells $\left(B_{0}\right)$, already this measure itself has a significant influence on the spatial pattern of the mean UHI intensity (Figure 5): the $\Delta T$ values follow the change in the built-up values. In detail, the main feature of this pattern in the central study area is that the isotherms show concentric-like shapes with values increasing from the suburbs towards the inner urban areas with a highest $\Delta T\left(>4^{\circ} \mathrm{C}\right)$ in the densely built-up centre. Deviations from this concentric-like shape occur in the western, northern and north-eastern parts where the isotherm of $2^{\circ} \mathrm{C}$ stretches

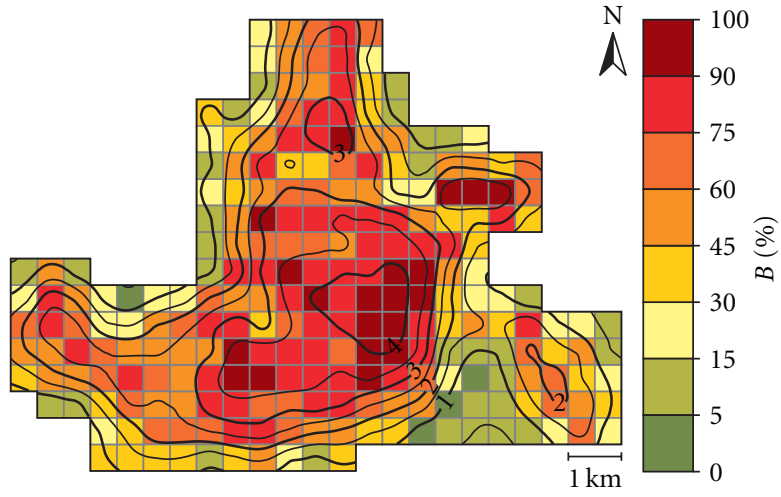

Figure 5: Spatial distribution of the built-up ratio (\%) and the modelled annual mean UHI intensity $\left({ }^{\circ} \mathrm{C}\right)$ in the study area of Novi Sad.

towards the outskirts. In addition, three island-like local maxima appear in the northern, north-eastern and eastern parts of the study area with values over $3^{\circ} \mathrm{C}, 2.5^{\circ} \mathrm{C}$ and $2^{\circ} \mathrm{C}$, respectively. The largest area with very low $\Delta T$ values, owing to the influence of the River Danube, can be found in the south-eastern part of the study area.

For the evaluation of the model estimation a comparison have been made using the dataset of Rimski Šančevi (rural) and Petrovaradin (urban) stations (1956-1992) (Figure 7). In this period, the observations were taken three times a day (07, 14 and 21 according to Central European Time), and the dataset contains the observed temperatures and daily maximum, minimum, average temperatures. Since there were not night time measurements, the daily minimum temperature data was used for the comparison. The difference of the two measured daily minimum temperature were calculated for each day of the mentioned 37 years. The average of these differences $\left(\Delta T_{\min }\right)$ can be considered as an approximate value of the annual mean urban heat island intensity $(\Delta T)$ [44]. The $\Delta T$ value for Petrovaradin calculated by the statistical model is $1.66^{\circ} \mathrm{C}$ and the measured $\left(\Delta T_{\min }\right)$ is $1.8^{\circ} \mathrm{C}$. This insignificant difference proves that the accuracy of the model estimation meets the requirements of the aim of this study.

5.2. Mapping of LCZs in the Study Area. The identification of climate zones in Novi Sad was based on information extracted from Google Maps [44], on guidance given by [7], and on the personal experiences of the second author (Figure 6). Since in Central-European urban areas the LCZ classes of compact highrise, open-set highrise and lightweight lowrise are missing, only the pattern of the remaining classes typical for this region were taken into account.

5.3. Recommendation for Station Sites of an Urban Climate Network. The planning of the possible sites of the stations of an urban climate network in Novi Sad is based on the structural features of the obtained UHI intensity pattern (Figure 5) and on the LCZ map (Figure 6). While searching 


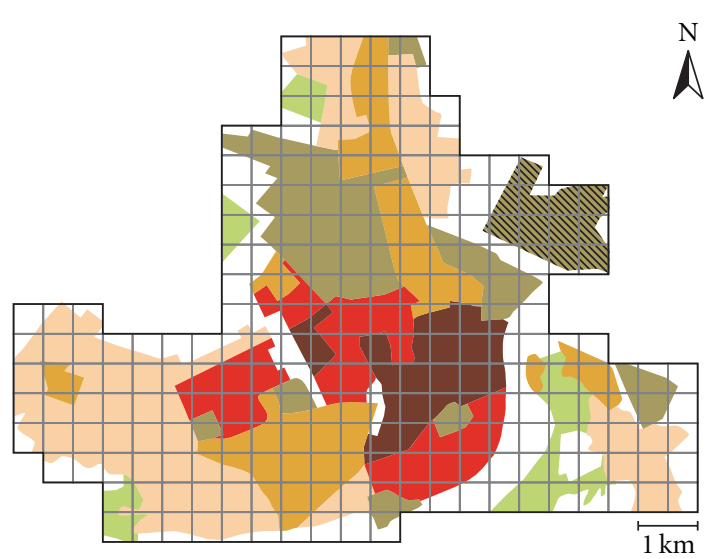

$$
\begin{array}{lll}
\text { Compact midrise } & \text { Extensive lowrise } \\
\text { Compact lowrise } & \text { High-energy industrial } \\
\text { Open-set midrise } & \text { Sparsely built } \\
\text { Open-set lowrise } &
\end{array}
$$

Figure 6: Spatial distribution of urban Local Climate Zones (based on [7]) occurring in the study area of Novi Sad.

for the appropriate (representative) locations, two criteria were considered:

(1) the stations should be located at around the high and low $\Delta T$ areas, as well as at around the areas of the local maxima and stretches assumed by the modelled UHI pattern,

(2) homogeneous LCZ areas a few hundred metres wide should be around the sites.

According to previous criteria, ten representative station locations in the urban area of Novi Sad have been detected (Figure $7(\mathrm{a})$ ). The locations represent the different neighbourhoods of the city, from the densely built-up area with medium narrow streets to the almost natural outskirts. The location numbered 1 is placed into the city's downtown with compact midrise landscape. The next three locations are situated in open-set midrise zones, with open natural surroundings among $>3$ stories tall buildings. Locations 5 and 6 characterise compact lowrise areas with tall buildings $<3$ stories and separeted by narrow streets, whereas locations 7 and 8 are in open-set lowrise zones, mostly with detached buildings separated by natural surfaces. The last two stations (9 and 10) are situated in industrial and warehouses zones (high-energy industrial and extensive lowrise). Also, it is important to mention that the two existing stations in the rural and in the urban (open-set midrise) area respectively (see Section 2), can be utilized to be a part of recommended urban climate network (Figure 7(a)). Furthermore, all stations would be set up at representative urban sites, according to scientific guidance $[3,45]$ (Figure 7(b)).
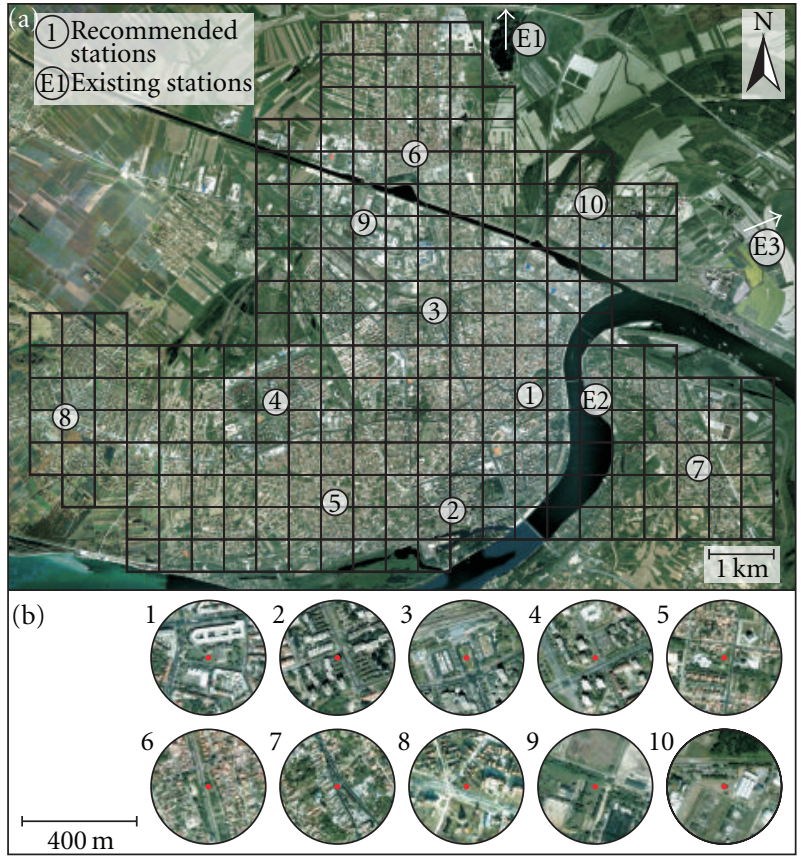

FIgURE 7: Satellite image of the study area in Novi Sad [45] with the existing stations and the recommended sites of a 10-station urban climate network (a) and the immediate surroundings (diameter$400 \mathrm{~m}$ ) of these sites (b) (E1-Rimski Šančevi, E2-Petrovaradin, E3-Kać).

\section{Conclusions}

According to the analysis of the urban heat island pattern in Novi Sad (Serbia), the main conclusions of this study are as follows.

(1) Urban area of Novi Sad with its more than 280,000 inhabitants is located in a rather homogeneously relieved region in the Great Hungarian Plain. Therefore, research of UHI pattern can be based on empirical modelling study of Balázs et al. [8], where datasets from Szeged and Debrecen (Hungary) were used to construct an empirical model. The study area has been divided into a $0.5 \mathrm{~km} \times 0.5 \mathrm{~km}$ mesh $(240$ cells) and has an extension of $1.5 \mathrm{~km}$ in and around Novi Sad.

(2) Evaluation of NDVI and built-up ratio values by cells varies from $0 \%$ in and around the Danube to over $90 \%$ in densely built-up downtown. Also, western, northern, north-eastern and eastern parts of Novi Sad's urban area are characterised as maximally built-up. These densely builtup area has a significant influence on the spatial pattern of the mean UHI intensity. The isotherms show concentric-like shapes with highest $\Delta T\left(>4^{\circ} \mathrm{C}\right)$ in the densely built-up centre and decrease towards the outskirts. A few local temperature islands (from $2^{\circ} \mathrm{C}$ to $3^{\circ} \mathrm{C}$ ) occurred in the suburbs with intensive built-up areas.

(3) Analysis of UHI intensity and some type of climate zone classifications (e.g., LCZs in [7]) is very important in order to detect sites which can be suggested for the stations of an urban climate network in Novi Sad. According to defined criteria, a representative 10-station network in the urban area has been determined in order to prepare further UHI 
research, that is, to monitor and provide measurement data of the urban heat island in the UCL of Novi Sad city, and to determine areas inside the city being less stressful for the citizens during heat waves using thermal comfort indices. The locations represent the complete range of the city's neighbourhoods, reaching from the densely built-up area with medium narrow streets to the almost natural outskirts. The result of this study is point out that the estimated mean UHI pattern and the distribution of some type of climate zone classifications in a city provide useful information in order to give recommendation on the possible sites of an urban UHI measurement network.

(4) The presented empirical model can be regarded as a useful tool for estimating the mean heat island patterns for small, Central European cities (typically of little vertical development) situated on a plain cities in the humid-continental climate type.

\section{Acknowledgments}

This research was supported by the Hungarian Scientific Research Fund (OTKA K-67626) and Serbian Ministry of Education and Science (Project no. 176020). The authors' special thanks are due to the anonymous reviewers for their several suggestions which improved the paper and to $\mathrm{Mr}$. M. Hämmerle (University of Freiburg, Germany) for the language revision of the paper.

\section{References}

[1] T. R. Oke, "The distinction between canopy and boundarylayer urban heat islands," Atmosphere, vol. 14, no. 4, pp. 269727, 1976.

[2] T. R. Oke, Boundary Layer Climates, Routledge, London ,UK, 2nd edition, 1987.

[3] T. R. Oke, "Initial guidance to obtain representative meteorological observation sites," WMO/TD 1250, 2004.

[4] I. D. Stewart, "Landscape representation and urban-rural dichotomy in empirical urban heat island literature, 1950 2006," Acta Climatologica et Chorologica Universitatis Szegediensis, vol. 40-41, pp. 111-121, 2007.

[5] I. D. Stewart and T. R. Oke, "Conference notebook-a new classification system for urban climate sites," Bulletin of the American Meteorological Society, vol. 90, pp. 922-923, 2009.

[6] I. D. Stewart, "Classifying urban climate field sites by "Local Climate Zones"', Urban Climate News, vol. 34, no. 4, pp. 8-11, 2009.

[7] I. D. Stewart and T. R. Oke, "Thermal differentiation of Local Climate Zones using temperature observations from urban and rural field sites," in Proceedings of the 9th Symposium, on the Urban Environment, Keystone, Colo, USA, August 2010.

[8] B. Balázs, J. Unger, T. Gál, Z. Sümeghy, J. Geiger, and S. Szegedi, "Simulation of the mean urban heat island using 2D surface parameters: empirical modelling, verification and extension," Meteorological Applications, vol. 16, no. 3, pp. 275287, 2009.

[9] L. Zentai, "Relief of central Europe," in Atlas of Central Europe, A. Rónai, Ed., p. 411, Szent István Társulat-Püski Kiadó, Budapest, Hungary, 1993.
[10] L. Lazić and D. Pavić, Climate of Banat, University of Novi Sad, Faculty of Science, Department of Geography, Tourism and Hotel Management, Novi Sad, Vojvodina, 2003.

[11] M. Kottek, J. Grieser, C. Beck, B. Rudolf, and F. Rubel, "World map of the Köppen-Geiger climate classification updated," Meteorologische Zeitschrift, vol. 15, no. 3, pp. 259-263, 2006.

[12] Z. Popov, Urban Climate, Methods, Measurements and Research, Republic Hydrometeorological Service, Belgrade, Serbia, 1994.

[13] Z. Popov, The Proposal for Setting Station Network to Monitor Urban Climate of in Novi Sad, Republic Hydrometeorological Service, Belgrade, Serbia, 1995.

[14] L. Lazić, S. Savić, and Ž. Tomić, "Analysis of the temperature characteristics and trends in Novi Sad area (Vojvodina, Serbia)," Geographica Pannonica, vol. 10, pp. 14-21, 2006.

[15] Z. Popov and S. Savić, "The urban climate of Novi Sad," in Proceedings of the 2nd Serbian Geographers' Congress-Towards Europe, p. 62, Book of Abstract, Novi Sad, Vojvodina, 2010.

[16] T. R. Oke, "Towards a prescription for the greater use of climatic principles in settlement planning," Energy and Buildings, vol. 7, no. 1, pp. 1-10, 1984.

[17] M. Svensson, I. Eliasson, and B. Holmer, "A GIS based empirical model to simulate air temperature variations in the Göteborg urban area during the night," Climate Research, vol. 22, no. 3, pp. 215-226, 2002.

[18] H.-S. Park, "Features of the heat island in Seoul and its surrounding cities," Atmospheric Environment, vol. 20, no. 10, pp. 1859-1866, 1986.

[19] J. Unger, Z. Sümeghy, Á. Gulyás, Z. Bottyán, and L. Mucsi, "Land-use and meteorological aspects of the urban heat island," Meteorological Applications, vol. 8, no. 2, pp. 189-194, 2001.

[20] K. Fortuniak, "An application of the urban energy balance scheme for a statistical modeling of the UHI intensity," in Proceedings of the 5th International Conference on Urban Climate, K. Klysik, T. R. Oke, K. Fortuniak et al., Eds., vol. 1, pp. 59-62, University of Lodz, Lodz, Poland, 2003.

[21] M.-J. Alcoforado and H. Andrade, "Nocturnal urban heat island in Lisbon (Portugal): main features and modelling attempts," Theoretical and Applied Climatology, vol. 84, no. 13, pp. 151-159, 2006.

[22] W. P. Lowry, "Empirical estimation of urban effects on climate: a problem analysis," Journal of Applied Meteorology, vol. 16, no. 2, pp. 129-135, 1977.

[23] J. Unger, Z. Sümeghy, and J. Zoboki, “Temperature cross-section features in an urban area," Atmospheric Research, vol. 58, no. 2, pp. 117-127, 2001.

[24] Y. Goldreich, "Computation of the magnitude of Johannesburg's heat island," Notos, vol. 19, pp. 95-106, 1970.

[25] W. Kuttler, A.-B. Barlag, and F. Roßmann, "Study of the thermal structure of a town in a narrow valley," Atmospheric Environment, vol. 30, no. 3, pp. 365-378, 1996.

[26] J. Unger, Z. Bottyán, Z. Sümeghy, and Á. Gulyás, "Urban heat island development affected by urban surface factors," Idöjárás-The Quaterly Journal of the Hungarian Meteorological Service, vol. 104, pp. 253-268, 2000.

[27] M. Szymanowski, "Spatial structure of the urban heat island in Wroclaw, Poland," in Proceedings of the 5th International Conference on Urban Climate, K. Klysik, T. R. Oke, K. Fortuniak, C. S. B. Grimmond, and J. Wibig, Eds., vol. 1, pp. 151-154, University of Łódź, Łódź, Poland, 2003.

[28] R. Giridharan, S. S. Y. Lau, S. Ganesan, and B. Givoni, "Urban design factors influencing heat island intensity in high-rise 
high-density environments of Hong Kong," Building and Environment, vol. 42, no. 10, pp. 3669-3684, 2007.

[29] N. J. Tapper, P. D. Tyson, I. F. Owens, and W. J. Hastie, "Modeling the winter urban heat island over Christchurch," Journal of Applied Meteorology, vol. 20, no. 4, pp. 365-376, 1981.

[30] K. Fortuniak and K. Klysik, "Intensity of the urban heat island in Lodz under winter conditions and its simple model," Acta Universitatis Lodziensis, Folia Geographica Physica, vol. 3, pp. 83-90, 1998.

[31] Z. Bottyán and J. Unger, "A multiple linear statistical model for estimating the mean maximum urban heat island," Theoretical and Applied Climatology, vol. 75, no. 3-4, pp. 233-243, 2003.

[32] Z. Bottyán, A. Kircsi, S. Szegedi, and J. Unger, "The relationship between built-up areas and the spatial development of the mean maximum urban heat island in Debrecen, Hungary," International Journal of Climatology, vol. 25, no. 3, pp. 405418, 2005.

[33] V. Bonacquisti, G. R. Casale, S. Palmieri, and A. M. Siani, "A canopy layer model and its application to Rome," Science of the Total Environment, vol. 364, no. 1-3, pp. 1-13, 2006.

[34] T. R. Oke and R. F. Fuggle, "Comparison of urban/rural counter and net radiation at night," Boundary-Layer Meteorology, vol. 2, no. 3, pp. 290-308, 1972.

[35] M. C. Moreno-Garcia, "Intensity and form of the urban heat island in Barcelona," International Journal of Climatology, vol. 14, no. 6, pp. 705-710, 1994.

[36] T. R. Oke, "Canyon geometry and the nocturnal urban heat island: comparison of scale model and field observations," Journal of Climatology, vol. 1, no. 3, pp. 237-254, 1981.

[37] J. Unger, "Intra-urban relationship between surface geometry and urban heat island: review and new approach," Climate Research, vol. 27, no. 3, pp. 253-264, 2004.

[38] K. P. Gallo and T. W. Owen, "Satellite-based adjustments for the urban heat island temperature bias," Journal of Applied Meteorology, vol. 38, no. 6, pp. 806-813, 1999.

[39] T. M. Lillesand and R. W. Kiefer, Remote Sensing and Image Interpretation, John Wiley \& Sons, New York, NY, USA, 1987.

[40] J. Cohen, P. Cohen, S. G. West, and L. S. Aiken, Applied Multiple Regression/Correlation Analysis for the Behavioral Sciences, Lawrence Erlbaum Associates, Hillsdale, NJ, USA, 2nd edition, 2003.

[41] J.-P. Chiles and P. Delfiner, Geostatistics, Modeling Spatial Uncertainty, Wiley Series in Probability and Statistics, New York, NY, USA, 1999.

[42] X. Emery, "Multigaussian kriging for point-support estimation: incorporating constraints on the sum of the kriging weights," Stochastic Environmental Research and Risk Assessment, vol. 20, no. 1-2, pp. 53-65, 2006.

[43] NASA Landsat Program, Landsat ETM+ scene L5187028. 02820060626, Orthorectified, USGS, Sioux Falls 26/06/2006, http://glcfapp.glcf.umd.edu:8080/esdi/index.jsp, 2008.

[44] Google maps, http://maps.google.com/, 2010.

[45] I. D. Stewart, "A systematic review and scientific critique of methodology in modern urban heat island literature," International Journal of Climatology, vol. 31, no. 2, pp. 200-217, 2011. 

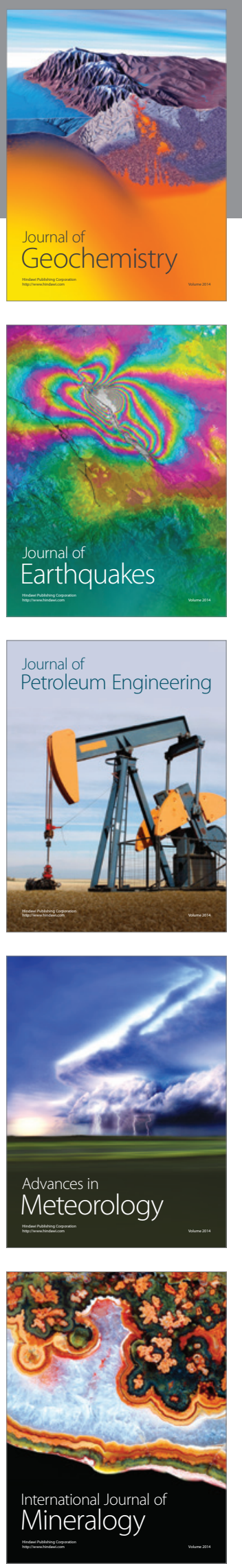
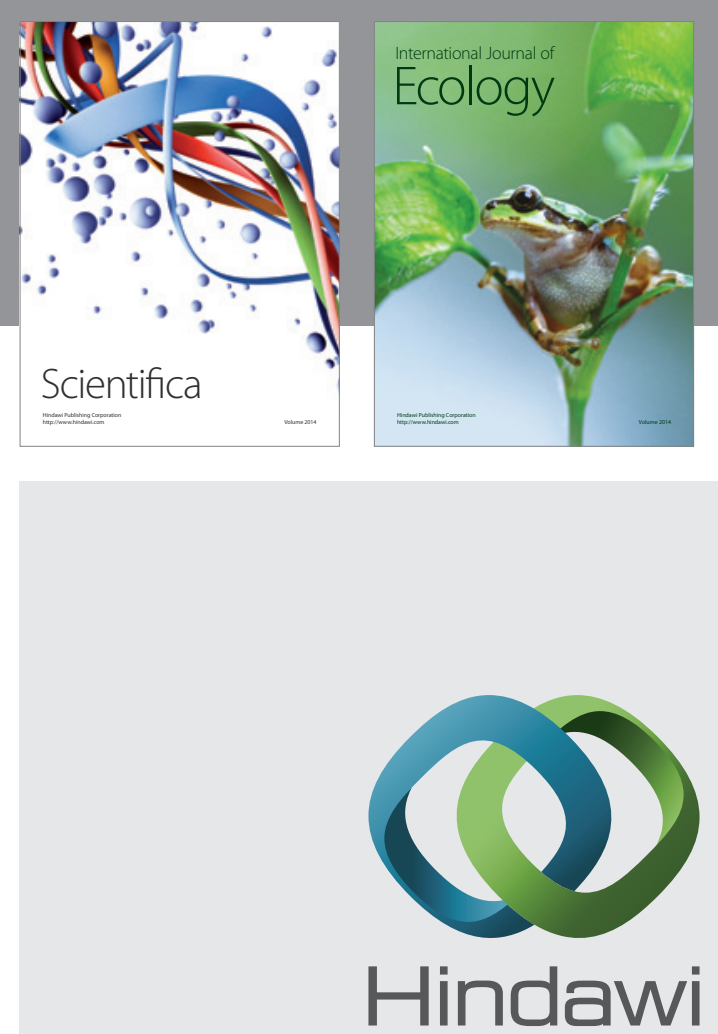

Submit your manuscripts at http://www.hindawi.com
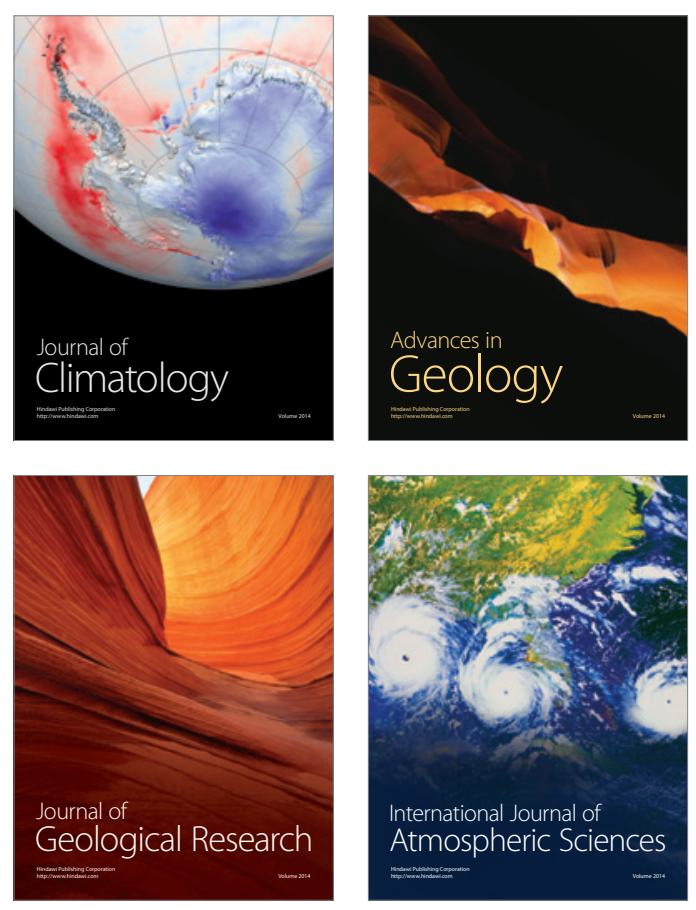
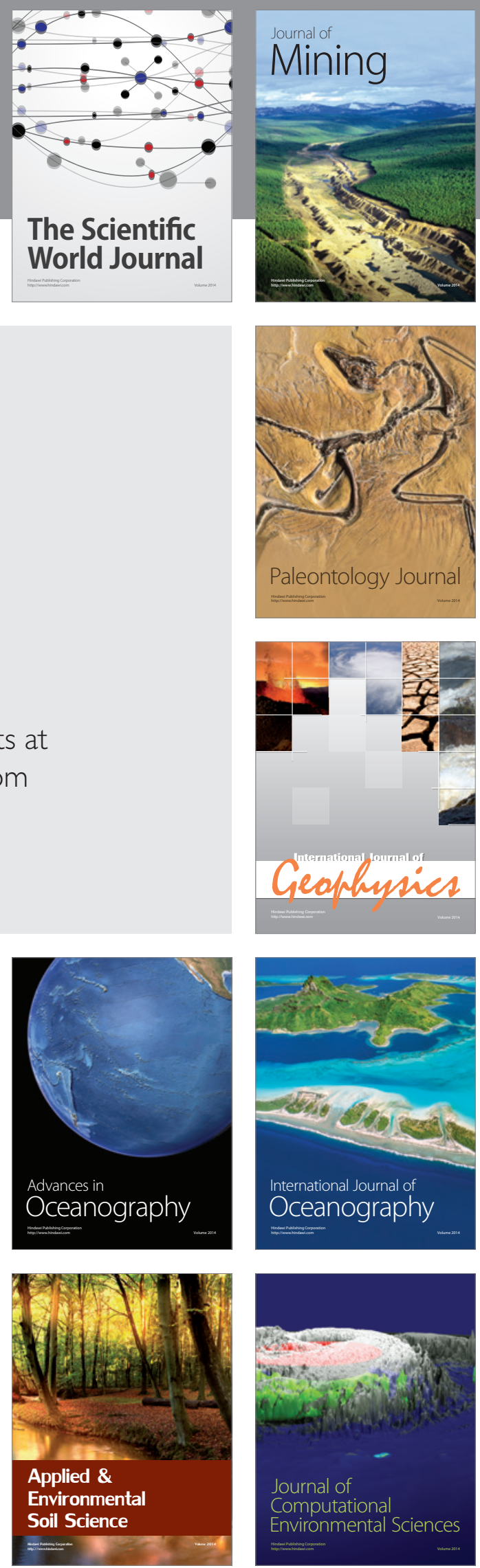